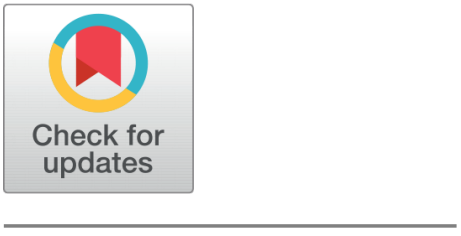

open ACCESS

Received: 16.12 .2020

Accepted: 30.12 .2020

Published: 11.01.2021

Citation: Jagadheesan R, Pandiyan J (2021) Temporal variations of large wading birds in the Point Calimere Wildlife Sanctuary, Tamil Nadu, India. Indian Journal of Science and Technology 14(1): 1-7. https://doi.or g/10.17485/IJST/v14i1.2251

* Corresponding author.

dunlinpandiyan@gmail.com

Funding: DST-SERB for funding the project (Ref No. SERB/LS-512/2013 dated-20.09.2013)

Competing Interests: None

Copyright: (c) 2021 Jagadheesan \& Pandiyan. This is an open access article distributed under the terms of the Creative Commons

Attribution License, which permits unrestricted use, distribution, and reproduction in any medium, provided the original author and source are credited.

Published By Indian Society for Education and Environment (iSee)

ISSN

Print: 0974-6846

Electronic: 0974-5645

\section{Temporal variations of large wading birds in the Point Calimere Wildlife Sanctuary, Tamil Nadu, India}

\author{
Rajendran Jagadheesan ${ }^{1,2}$, Jeganathan Pandiyan ${ }^{1,2 *}$ \\ 1 Department of Zoology and Wildlife Biology, A.V.C. College (Autonomous), Mannampandal, \\ 609 305, Tamil Nadu, India \\ 2 The Institution affiliated to the Bharathidasan University, Tiruchirapalli, Tamil Nadu, India
}

\section{Abstract}

Objectives: To assess the temporal variations of the large wading birds in the Point Calimere Wildlife Sanctuary and to suggest management recommendations for the better management of the wading birds visited in the sanctuary seasonally. Methods and Statistical analysis: The population characteristic of large wading birds was carried out by employing a 'direct count' method. The one-way analysis of variance (ANOVA) was performed to understand the impact of various seasons on the population characteristics of large wading birds. Findings: In total, 13 species of large wading birds were observed. Among the 13 species, the Black-headed Ibis and Painted stork are Near Threatened category (IUCN, 2020). Greater Flamingos showed the highest density than the other large wading birds observed from the PCWLS. The density, diversity and species richness of large wading birds were relatively greater in monsoon than the other seasons studied. The population characteristics of large wading birds varied significantly among the months and seasons $(P<0.001)$. Novelty and applications : The diversity of large wading birds is declined when compared to the previous studies. The study revealed that the PCWLS is required intensive assessment of the various ecological factors of the sanctuary for managing various species of waterbirds visited seasonally.

Keywords: Conservation; large wading birds; population; waterbirds; wetlands

\section{Introduction}

Waterbirds are persistently associated with the freshwater, coastal and marine habitats ${ }^{(1)}$ Numerous species of waterbirds are well known for their long-distance migration ${ }^{(2,3)}$. The waterbirds migrate annually from their breeding grounds to wintering grounds to meet out their energetic demands ${ }^{(4)}$. More than 2000 wetlands about 4.1 million hectares of wetlands are identified in India ${ }^{(5)}$. All these wetlands are supporting several species of migratory waterbirds and shorebirds, in which, 42 wetlands are designated as Ramsar sites in India ${ }^{(6)}$. In addition to that 465 Important Bird Areas (IBA) are also 
supporting various species of waterbirds in India seasonally ${ }^{(7)}$.

Generally, the waterbirds inhabit wetlands for feeding, breeding, nesting or roosting ${ }^{(8)}$. Waterbirds are effectively using the wetlands as a most viable habitat; on the other hand, the wetlands are also supporting numerous species of waterbirds since the wetlands providing necessary nutrients for the waterbirds. In the wetland ecosystem the waterbirds are regarded as the most significant role in the food web and trophic structure ${ }^{(9)}$. The abundance and distribution of waterbirds are influenced by several factors in which the temporal factors are one of the major ecological factors, which is playing a major role in the viability of the population of waterbirds ${ }^{(3)}$. The abundance and distribution of waterbirds mostly depend on the quality of wetlands ${ }^{(10)}$. In addition to that, the waterbirds are one of the good bioindicators and which is facilitating to the exploration of various environmental problems ${ }^{(11)}$. Since the wetlands are providing sufficient energy for the various species of waterbirds the wetlands are attracting migratory and resident bird species waterbirds ${ }^{(12)}$. Nevertheless, the assessment of bird density, diversity and species richness of waterbirds is the most critical aspect because these characteristics could enable the status of the various species of waterbirds in a given wetland habitat ${ }^{(13,14)}$.

The Point Calimere Wildlife Sanctuary (PCWLS) is an important wetland in southern India and is the only Ramsar site in Tamil Nadu, India. The PCWLS is supporting numerous species of waterbirds annually ${ }^{(12,15-17)}$. But a recent study described that the population of waterbirds in PCWLS is declined due to various ecological factors ${ }^{(18)}$. In India, wetlands are facing severe threats due to various pollutions ${ }^{(19)}$. The population of waterbirds is declined due to the degradation of wetlands through various natural processes and man-made activities. Therefore the present study intended to evaluate the density, diversity and species richness of waterbirds especially large wading birds to understand their status and distribution in the PCWLS and to suggest the management recommendations of the sanctuary.

\section{Materials and Methodology}

\subsection{Study Area}

The Point Calimere Wildlife Sanctuary (PCWLS), is situated in the Vedarnyam swamp at $10^{\circ} 18^{\prime \prime} \mathrm{N}, 79^{\circ} 51^{\prime \prime} \mathrm{E}$ in the state of Tamil Nadu in Nagapattinam District, India (Figure 1). The sanctuary belongs to the bar-built category under the four basic sub-classification of coastal habitats ${ }^{(20)}$. The PCWLS receives water only during the monsoon season. The swampland is located in the western part of the PCWLS and the total area of the swamp belt is $30 \mathrm{~km}$ long and $9 \mathrm{~km}$ wide, which is the viable and significant habitat for waterbirds. Inside the swamp area, two salt production companies are functioning with large scale production of industrial slats. The sanctuary will get the rainwater during the monsoon season during the month of October - December. The average temperature of the sanctuary is $32^{\circ} \mathrm{C}$. The sanctuary is supporting numerous species of migratory, resident migratory and resident waterbirds annually ${ }^{(18)}$.

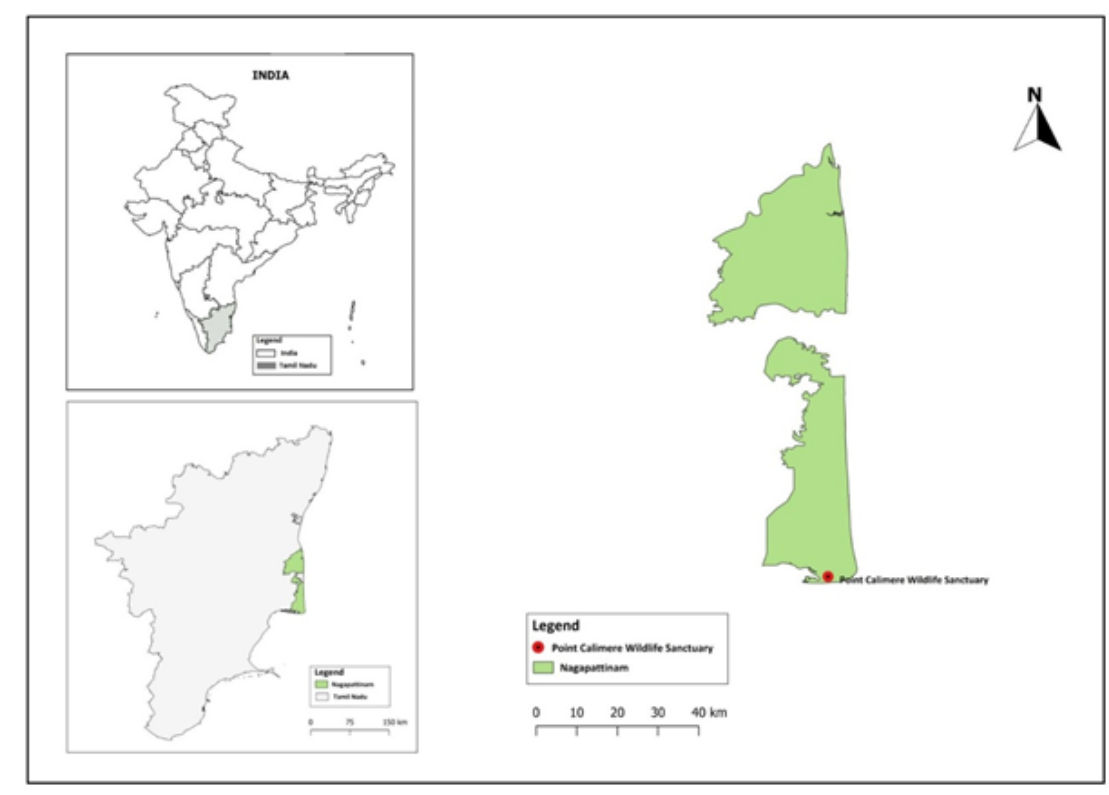

Fig 1. Map of the study area point Calimere Wildlife Sanctuary, Tamil Nadu, India 


\subsection{Waterbird counts}

The study was conducted from 2015 to 2016 covering pre-migratory, migratory and post-migratory seasons. One hectare of the sampling area was selected based on the aggregation of large wading birds in the sanctuary. The birds were counted by using binocular (7x50) and spotting scope (20x60). The total count (direct count) method was applied for the bird survey fortnightly at each month, birds were counted individually for the respective species ${ }^{(3,21)}$ for the entire study periods. Observations were made from early morning $06.00 \mathrm{am}$ to $11.00 \mathrm{am}$. No birds were disturbed during the survey. The arrival or departure of the large wading birds was cautiously identified and counted.

\subsection{Data analysis}

The density of large wading birds was calculated as a number per hectare ${ }^{(3)}$ and the species richness and diversity were also calculated by using standard procedures ${ }^{(22,23)}$. The one-way analysis of variance (ANOVA) was performed to understand the time factor such as seasons and months in relation to the population characteristics of large wading birds such as density, diversity and species richness. The data were analysed by using the Minitab 18.0 and SPSS 25.0 and the results were interpreted with standard statistical procedures ${ }^{(24)}$.

\section{Results and Discussion}

The study found 13 species of large wading birds from the Point Calimere Wildlife Sanctuary, during the study period. However, among the 13 species, two species were Near Threatened category such as Black-headed Ibis and Painted stork, four were resident and the rest of the species were resident migratory (RM) categories (Table 1). The Greater Flamingos showed the highest density (452.6 $\pm 94.64 \mathrm{No} . / \mathrm{ha})$ and the Striated heron showed minimum density $(0.1 \pm 0.07 \mathrm{No}$./ha) when compared to the other species (Table 1). The density, diversity and species richness of large wading birds were relatively greater in monsoon than the other seasons studied (Table 2). The month of January, 2016, showed the highest density, diversity and species richness when compared to the other months studied (Figures 2, 3 and 4). The large wading bird density, diversity and species richness showed significant differences among the months and seasons studied $(\mathrm{p}<0.001)$ (Table 3, Figures 3 and 4$)$.

Table 1. Density of large wading birds (No./Ha) recorded from the Point Calimere Wildlife Sanctuary from August 2015- April 2016.(Values

\begin{tabular}{lll} 
& & are Mean \pm SE) \\
\hline S. No. & Species Name & Density (No./ha.) \\
\hline 1 & Cattle egret (Egretta garzetta) & $1.1 \pm 1.14$ \\
2 & Great egret (Ardea alba) & $31.0 \pm 3.26$ \\
3 & Inter-mediate egret (Ardea intermedia) & $16.3 \pm 2.95$ \\
4 & Little egret (Egretta garzetta) & $40.0 \pm 5.03$ \\
5 & Western-reef egret (Egretta gularis) & $1.8 \pm 0.48$ \\
6 & Striated heron (Butorides striata) & $0.1 \pm 0.07$ \\
7 & Indian pond heron (Ardeola grayii) & $23.4 \pm 3.79$ \\
8 & Grey heron (Ardea cinerea) & $4.9 \pm 0.90$ \\
9 & Purple heron (Ardea purpurea) & $0.3 \pm 0.16$ \\
10 & Greater flamingo (Phoenicopterus roseus) & $452.6 \pm 94.64$ \\
11 & Black-headed ibis (Threskiornis melanocephalus) & $7.2 \pm 3.44$ \\
12 & Eurasian spoonbill (Platalea leucorodia) & $19.0 \pm 4.64$ \\
13 & Painted stork (Mycteria leucocephala) & $88.8 \pm 12.55$ \\
\hline
\end{tabular}


Table 2. Seasonal variation of large wading bird density(No./Ha) recorded from the Point Calimere Wildlife Sanctuary during August2015April 2016. (Values are Mean \pm SE).

\begin{tabular}{|c|c|c|c|c|}
\hline \multirow{2}{*}{ S.No. } & \multirow{2}{*}{ Large Wading birds } & \multicolumn{3}{|c|}{ Point Calimere Wildlife Sanctuary Seasons (Aug-2015 to Apr-2016) } \\
\hline & & Pre-Monsoon & Monsoon & Post-Monsoon \\
\hline 1 & Cattle egret & - & $3.44 \pm 3.444$ & - \\
\hline 2 & Great egret & $18.72 \pm 3.762$ & $45.61 \pm 5.436$ & $28.78 \pm 5.851$ \\
\hline 3 & Intermediate egret & $3.17 \pm 1.898$ & $24.61 \pm 5.891$ & $21.33 \pm 5.272$ \\
\hline 4 & Little egret & $14.28 \pm 3.004$ & $66.89 \pm 9.673$ & $38.94 \pm 7.304$ \\
\hline 5 & Western reef egret & - & $3.78 \pm 1.195$ & $1.89 \pm 0.626$ \\
\hline 6 & Striated heron & $0.06 \pm 0.056$ & $0.11 \pm 0.111$ & $0.28 \pm 0.195$ \\
\hline 7 & Indian pond heron & $20.11 \pm 9.868$ & $30.83 \pm 3.786$ & $19.39 \pm 4.295$ \\
\hline 8 & Grey heron & $4.11 \pm 1.075$ & $9.72 \pm 1.988$ & $0.89 \pm 0.411$ \\
\hline 9 & Purple heron & $0.22 \pm 0.173$ & $0.78 \pm 0.461$ & - \\
\hline 10 & Greater flamingo & $412.33 \pm 119.465$ & $907.22 \pm 216.36$ & $38.28 \pm 18.62$ \\
\hline 11 & Black headed ibis & - & $21.33 \pm 9.657$ & $0.39 \pm 0.389$ \\
\hline 12 & Eurasian spoonbill & $9.61 \pm 3.111$ & $47.5 \pm 10.859$ & - \\
\hline 13 & Painted stork & $152.5 \pm 23.6$ & $106.06 \pm 16.282$ & $7.83 \pm 3.163$ \\
\hline
\end{tabular}

Table 3. Seasonal variations of large wading birddensity, diversity and richness recorded from the Point Calimere Wildlife Sanctuary during August 2015- April 2016. (Values are Mean \pm SE).

\begin{tabular}{llllll}
\hline \multirow{2}{*}{ S.No. } & $\begin{array}{l}\text { Population Characteristics of large wading } \\
\text { birds }\end{array}$ & Seasons & & ANOVA \\
\cline { 2 - 5 } & Pre-Monsoon & Monsoon & Post-Monsoon & Palue \\
\hline 1 & Density (No./ha.) & $635.11 \pm 142.457$ & $1267.89 \pm 236.281$ & $158 \pm 31.118$ & $\mathrm{P}<0.001$ \\
2 & Diversity (H') & $0.01 \pm 0.002$ & $0.02 \pm 0.003$ & $0.01 \pm 0.001$ & $\mathrm{P}<0.001$ \\
3 & Richness (Number of species) & $4.94 \pm 0.557$ & $8.06 \pm 0.482$ & $4.78 \pm 0.712$ & $\mathrm{P}<0.001$ \\
\hline
\end{tabular}

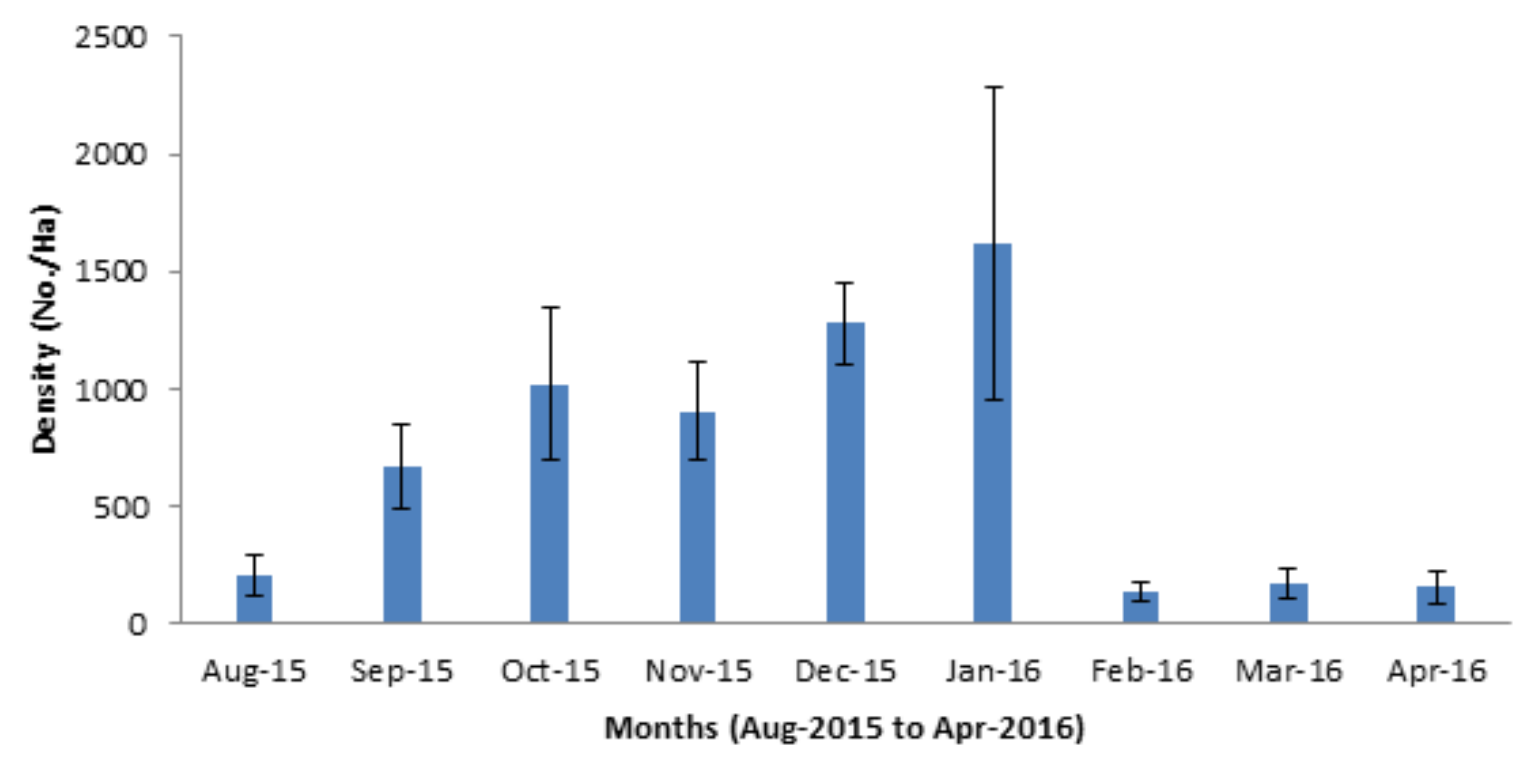

Fig 2. Monthly variations of large wading bird density(No./ha.) recorded from the Point Calimere Wildlife Sanctuary, Kodikkarai fromAugust 2015- April 2016. (Values are Mean \pm SE). 


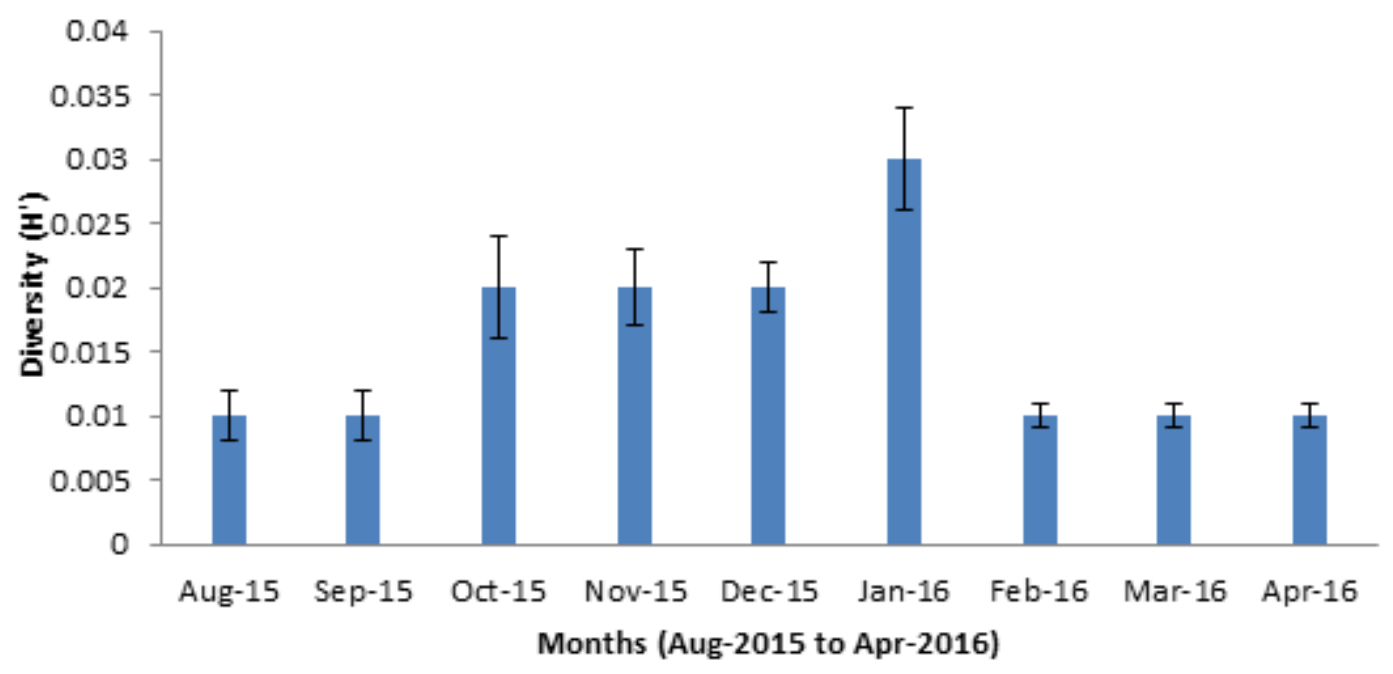

Fig 3. Monthly variations of large wading bird diversity $\left(\mathrm{H}^{\prime}\right)$ recorded from the Point Calimere Wildlife Sanctuary, Kodikkarai from August 2015- April 2016. (Values are Mean \pm SE).

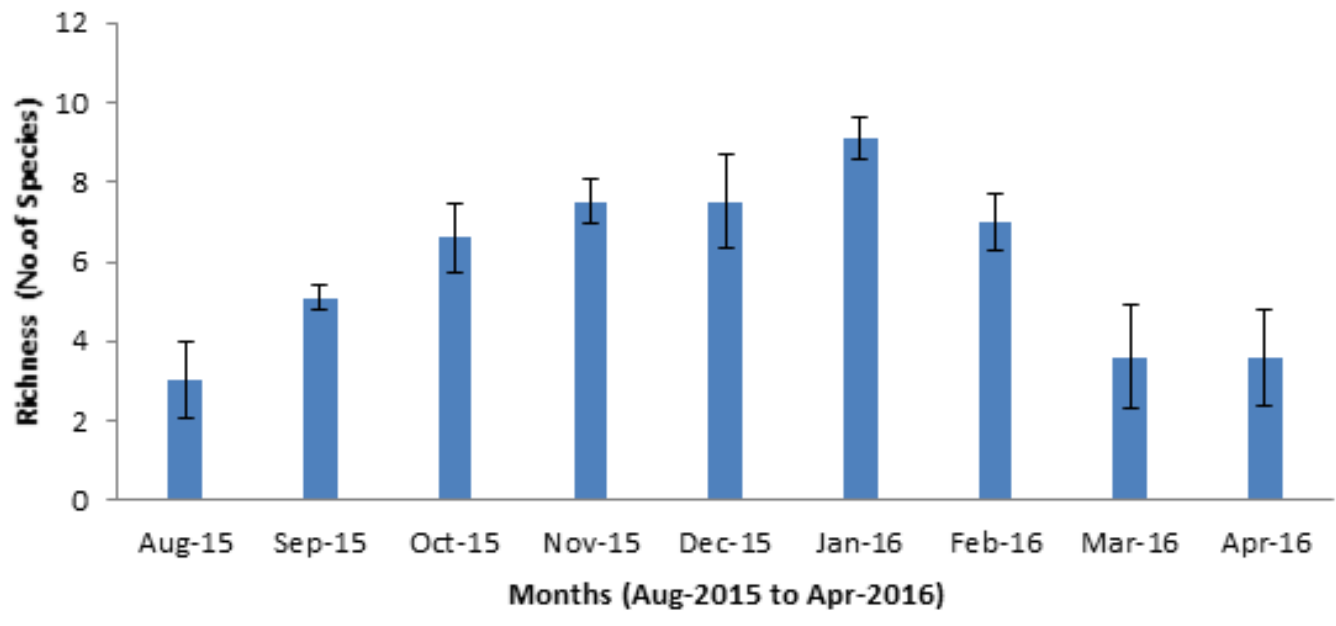

Fig 4. Monthly variations of species richness of large wading birds recorded from the Point Calimere Wildlife Sanctuary, Kodikkaraifrom August 2015- April 2016. (Values are Mean \pm SE).

The study found that 13 species of large wading birds recorded from the sanctuary, but the results revealed that the species of large wading birds and their population is declined when compared to the previous studies. In fact, a study reported that more than 250 species of waterbirds were using the Point Calimere Wildlife Sanctuary (PCWLS) ${ }^{(25)}$. Another study has revealed that the sanctuary supports 110 species of waterbirds in which 34 large wading birds have effectively used the sanctuary seasonally ${ }^{(26)}$, several species of large wading birds used the swamp lands PCWLS as viable habitats during their migration ${ }^{(27)}$ A study envisaged that various species of waterbirds including shorebirds utilized the swamp lands of PCWLS as significant foraging grounds ${ }^{(12)}$. Studies mentioned that the PCWLS sanctuary has supported various species of waterbirds especially numerous species of large wading birds as a potential feeding ground annually ${ }^{(28-30)}$. One of the Ramsar's Reports (2002) described that 31 large wading birds out of 119 waterbird species were recorded from the PCWLS ${ }^{(31)}$. A report from the PCWLS 
inferred that nearly 23 species of large wading birds were recorded from the Point Calimere Wildlife Sanctuary ${ }^{(32)}$. However, the present study found that the population and diversity of large wading birds are lower than the previous studies. The decline of the large wading bird population in the PCWLS might be due to the effect of various ecological factors that degraded the sanctuary. PCWLS is reported degraded as a result of human pressures ${ }^{(17)}$ and various ecological factors and pollution ${ }^{(12)}$. Another study also reported that the population of waterbirds is drastically declined in the PCWLS when compared to the previous studies due to various ecological pressures ${ }^{(3)}$

The study found that the bird density, diversity and species richness showed significant variations among the seasons and months $(\mathrm{P}<0.001)$. It is also inferred that the time factors such as seasons and months are playing a major role in the population characteristic of large wading birds in a given wetland habitat. Several studies stated that the seasons and years could influence the abundance, density and species richness of waterbird species. In addition to that the temporal factors such as annual, seasons and months etc., could regulate the population of waterbirds temporally since these factors are facilitating the dispersal, immigration, emigration of avian communities. Studies also described that the population and species composition varied among the various species of waterbirds driven by the seasons and which could be associated with the immigration and emigration of waterbirds ${ }^{(33-36)}$. However, the waterbird species diversity and species composition are governed by the quality of aquatic habitats such as resource availability, nesting and roosting sites. ${ }^{(37-39)}$

The large wading birds are feeding, nesting, roosting on any kind of aquatic habitat with appropriate water level. The population characteristics of large wading birds could be changed on the basis of water level, availability of food, physical and chemical features of water and soil, etc. A few studies have been documented in relation to the status and distribution of large wading birds and their requirements in a given wetland rather than major attention of waterbirds. Studies also implied that the species composition and viability of large wading birds are purely determined by the size of wetlands, existences of prey, depth of water, vegetation cover and slopes of water body etc. ${ }^{(40,41)}$

\section{Conclusion}

Globally, several wetlands are degraded due to the negative influence of various ecological factors ${ }^{(40,42)}$. Indeed, the wetland habitats are vanishing and the wetlands should be conserved because the wetlands are supporting numerous species of waterbirds and other aquatic organisms seasonally. Nevertheless, the Point Calimere Wildlife Sanctuary is one of the Ramsar sites in India and which is also providing suitable habitat for various species of waterbirds including migratory, resident migratory and resident waterbird species annually. The current study found that 13 species of large wading birds and are effectively using the Point Calimere Wildlife Sanctuary as potential foraging grounds seasonally. But the results of the present study showed that the PCWLS is not supporting a maximum number of large wading birds when compared to the previous studies. Therefore, the PCWLS is to be assessed with an intensive survey of various ecological factors such as physical and chemical characteristics of soil and water, assessment of food and prey availability for the waterbirds, threats, pollution, and other factors that are directly or indirectly affecting the waterbird communities for proper monitoring, management and conservation of waterbirds.

\section{Acknowledgement}

The authors RJ and JP express their sincere thanks to DST-SERB for funding the project (Ref No. SERB/LS-512/2013 dated20.09.2013). The authors also thank the Management of AVC College and Department of Zoology and Wildlife Biology for providing the necessary facilities for the said project.

\section{References}

1) Ogden JC, Baldwin JD, Bass OL, Browder JA, Cook MI, Frederick PC, et al. Waterbirds as indicators of ecosystem health in the coastal marine habitats of Southern Florida: Conceptual ecological models. Ecological Indicators. 2014;1:128-147. Available from: https://doi.org/10.1016/j.ecolind.2014.03.008.

2) Cramp S, Simmons K. The Birds of the Western Palearctic;vol. III. Oxford. Oxford University Press. 1983. Available from: https://eunis.eea.europa.eu/ references/1692.

3) Pandiyan J, Asokan S. Habitat use pattern of tidal mud and sand flats by shorebirds (charadriiformes) wintering in southern India. Journal of Coastal Conservation. 2016;20(1):1-11. Available from: https://dx.doi.org/10.1007/s11852-015-0413-9.

4) Pandiyan J. Ecology of shorebirds in the tidal flats of Cauvery deltaic region of southern India. Tiruchirappalli, Tamil Nadu, India. 2002. Available from: http://hdl.handle.net/10603/112218.

5) Alfred JRB, Nandi NC. Faunal diversity in Indian wetlands. ENVIS Newsletter. 2000;6(2):1-3. Available from: https://envisjnu.tripod.com/envnews/ aprmay00/faunal.html.

6) Report Ramsar site-Envis Centre. 2020. Available from: http://wiienvis.nic.in/Database/ramsar_wetland_sites_8224.aspx.

7) Islam MZ, Rahmani AR. Important Bird Areas in India. Priority sites for conservation. International Bird Conservation Network. BNHS and Birdlife International. 2004. 
8) Kumar A, Sati JP, Tak PC, Alfred JRB. Handbook on Indian Wetland Birds and their Conservations. and others, editor;Zoological Survey of India. 2005. Available from: http://faunaofindia.nic.in/PDFVolumes/hpg/022/index.pdf.

9) Studds CE. Rapid population decline in migratory shorebirds relying on Yellow Sea tidal mudflats as stopover sites. Nature Communication. 2017;8. Available from: https://doi.org/10.1038/ncomms14895.

10) Pandiyan J, Jagadheesan R, Karthikeyan G, Mahboob S, Al-Ghanim KA, Al-Misned F, et al. Probing of heavy metals in the feathers of shorebirds of Central Asian Flyway wintering grounds. Scientific Reports. 2020;10(1). Available from: https://dx.doi.org/10.1038/s41598-020-79029-z.

11) $\mathrm{Mu} \mathrm{T}$, Wilcove DS. Upper tidal flats are disproportionately important for the conservation of migratory shorebirds. Proceedings of the Royal Society B: Biological Sciences. 2020;287(1928). Available from: https://dx.doi.org/10.1098/rspb.2020.0278.

12) Manikannan R. Diversity of Water birds in the point Calimere wildlife sanctuary, Tamil Nadu, India. Tiruchirappalli, Tamil Nadu, India. 2011.

13) Nagarajan R, Thiyagesan K. Waterbirds and substrate quality of the Pichavaram wetlands, southern India. Ibis. 1996;138(4):710-721. Available from: https://dx.doi.org/10.1111/j.1474-919x.1996.tb04773.x.

14) Balachandran S. [14]Balachandran S. Avian Diversity in Coastal Wetlands ofIndia and their Conservation Needs. International day for biological diversity, Marine biodiversity. 2012.

15) Sampath K. Studies on the ecology of shorebirds (Aves: Charadriiformes) of the Great Vedaranyam Swamp and the Pichavaram mangroves of India. Parangipettai. 1989.

16) Sampath K, Krishnamurthy K. Shorebirds (Charadriiformes) of the Pichavaram mangroves, Tamil Nadu, India. Wader Study Group Bulletin. 1990;58:2427. Available from: https://sora.unm.edu/node/120940.

17) Balachandran S. The decline in wader populations along the east coast of India with special reference to Point Calimere, south-east India. In: Galbraith CA, Stroud DA, editors. The Stationery Office. 2006;p. 296-301.

18) Jagadheesan R, Pandiyan J. Population characteristics of migratory shorebirds in the Point Calimere Wildlife Sanctuary. Journal Scientific Transactions in Environment Technovation. 2015;10(1):31-36.

19) Agoramoorthy G, Chen FA, Hsu MJ. Threat of heavy metal pollution in halophytic and mangrove plants of Tamil Nadu, India. Environmental Pollution. 2008;155:320-326. Available from: https://dx.doi.org/10.1016/j.envpol.2007.11.011.

20) Pritchard DW. What is an estuary -physical point. In: Lauff GH, editor. Estuaries. American Association for the Advancement of Science. 1967;p. 3-5.

21) Yates MG, Goss-Custard JD. A comparison between high water and low water counts of shorebirds on the Wash, east England. Bird Study. 1991;38:179-187. Available from: https://dx.doi.org/10.1080/00063659109477087.

22) Verner J. Assessment of census techniques. In: Johnston RF, editor. Current ornithology. New York. Plenum Press. 1985;p. 247-302. Available from: https://doi.org/10.1007/978-1-4613-2385-3_8.

23) Shannon CE, Wiener W. The mathematical theory of communication. Urban III. Illinois University Press. 1949.

24) Sokal RR, Rohlf FI. Biometry: the principles and practice of statistics in biological research. 2012.

25) Ali S. Point Calimere as a refuge for wintering shorebirds. Journal Bombay Natural History Society. 1963;60(2):458-460.

26) Sugathan R. Some interesting aspects of the avifauna of the Point Calimere Sanctuary. Journal of Bombay Natural History Society. 1983;79(3):567-575.

27) Hussain SA. Occurrence of the Broadtailed Grass Warbler. Journal of Bombay Natural History Society. 1977;73(2):400-401.

28) Manakadan R. Ecology of waterbirds of Point Calimere Sanctuary with special reference to impact of salt works. Bombay. 1992.

29) Manakadan R. Impact of salt works on waterbirds and their habitats in the Great Vedaranyam Swamp, Ecology of Point Calimere Sanctuary: An Endangered Ecosystem. In: Daniel JC, Rao YN, editors. Bombay Natural History Society. 1988;p. 95-131.

30) Manakadan R. Impact of salt works on the status, population of the Greater Flamingo Phoenicopterusruberroseus and the Lesser Flamingo Phoeniconaias minor in the Great Vedaranyam Swamp;vol. 92 of 3. Bombay.. Bombay Natural History Society. 1995.

31) Ramsar Site Report. Information sheet on Ramsar Wetlands (RIS). Categories approved by recommendations 4.7 of the Conference of the Contracting Parties. 2002. Available from: http://www.wetlands.org/reports/ris/2IN01en.pdf.

32) Baruah AD. Point Calimere Wildlife and Bird Sanctuary. Tamil Nadu Forest Department Publication, Nagapattinam. 2005.

33) DuBowy PJ. Waterfowl Communities and Seasonal Environments: Temporal Variability in Interspecific Competition. Ecology. 1988;69(5):1439-1453. Available from: https://dx.doi.org/10.2307/1941641.

34) Romano M, Barberis I, Pagano F, Maidagan J. Seasonal and interannual variation in waterbird abundance and species composition in the Melincu saline lake, Argentina. European Journal of Wildlife Research. 2005;51(1):1-13. Available from: https://dx.doi.org/10.1007/s10344-005-0078-z.

35) Pandiyan J, Asokan S, Thiyagesan K, Nagrajan R. Use of tidal flats in the Cauvery Delta region of SE India by shorebirds, gulls and terns. Wader Study Group Bulletin. 2006;109:105-111. Available from: https://www.waderstudygroup.org/article/3160.

36) Morrison CA, Robinson RA, Clark JA, Risely K, Gill JA. Recent population declines in Afro-Palaearctic migratory birds: the influence of breeding and non-breeding seasons. Diversity and Distributions. 2013;19(8):1051-1058. Available from: https://dx.doi.org/10.1111/ddi.12084.

37) Wiens JA. The ecology of bird communities. Cambridge. Cambridge University Press. 1989.

38) Mu T, Wilcove DS. Data from: Upper tidal flats are disproportionately important for the conservation of migratory shorebirds. Dryad Digital Repository. 2020. Available from: https://doi.org/10.5061/dryad.gmsbcc2jb.

39) Griffis-Kyle KL, Beier P. Migratory strategy and seasonal patterns of bird diversity in relation to forest habitat. Am MidlNat. 2000;153:153-153.

40) Pandiyan J, Mahboob S, Jagadheesan R, Elumalai K, Krishnappa K, Al-Misned F, et al. A novel approach to assess the heavy metal content in the feathers of shorebirds: A perspective of environmental research. Journal of King Saud University - Science. 2020;32(7):3065-3071. Available from: https://dx.doi.org/10.1016/j.jksus.2020.08.014.

41) Mohanraj S, Pandiyan J. Invasion of shorebirds into inland wetlands of Periyakulam Lake. Journal Scientific Transactions in Environment Technovation. 2015;7(3):113-117.

42) Pandiyan J, Asokan S, Nagarajan R. Habitat utilization and assemblage patterns of migratory shorebirds at stop-over sites in Southern India. Stilt. 2010;p. 36-44. Available from: https://awsg.org.au/wp-content/uploads/2020/11/Stilt-58.pdf. 